\title{
Service Strategy Based on Tri Kaya Parisudha (TKP) Values
}

\author{
Ni Nyoman Kerti Yasa Putu Gde Sukaatmadja \\ I G. A. Ketut Giantari Putu Laksmita Dewi Rahmayanti \\ Faculty of Economics and Business, Udayana University
}

\begin{abstract}
This research was conducted with the background of service strategy as one of the business strategies that has been very popular to improve business performance. The service strategy implemented in service sector SMEs in Bali is certainly inseparable from the values of local wisdom hold by service sector SMEs businessmen in Bali. One of the local wisdom values in Bali that can merge with providing services to customers is the values of Tri Kaya Parisudha (TKP). Therefore, this study aims to develop and explore service strategies based on TKP values. This study uses a qualitative approach with the stakeholders of SMEs in Bali as the informant, consisting of service sector SME businessmen, cultural experts, experts in Hinduism, and academics. There are 10 informants in this study. The results show that the service sector SMEs in Bali has been implementing the Tri Kaya Parisudha valuesbased service strategy. This service strategy based on Tri Kaya Parisudha values includes three dimensions under the elements of Tri Kaya Parisudha, namely Manacika values, Wacika values, and Kayika values.Manacika's value-based service strategy, expressed as always having thoughts or desires to provide the best service, to bring benefits to customers, and to maintain a good relationship with customers. Wacika's value-based service strategy consists of: always speaking politely to customers, softly, and honestly about the products offered to customers. Kayika's value-based service strategy includes: always respond quickly in helping customers and pay special attention to customer problems.
\end{abstract}

Keywords: service strategy, Tri Kaya Parisudha, Manacika, Wacika, Kayika

DOI: $10.7176 / \mathrm{EJBM} / 11-28-11$

Publication date:October $31^{\text {st }} 2019$

\section{INTRODUCTION}

A service strategy is one of the business strategies implemented by SMEs in Bali, especially SMEs engaged in the service sector. These service sector SMEs include SMEs in the culinary, beauty salon, barber, laundry, repair shop, and retail fields. A service strategy is very important because it is directly related to the customers. From the business side, companies can communicate with customers regarding the services provided. Through good service, the company can satisfy consumers which results in an increase in sales turnover. Therefore, the service strategy becomes very strategic to improve business performance. This is shown from the results of the study of Kwak and Kim (2016); Benyoussef and Zaiem (2017); Ambroise et al. (2018); which shows the results that a better service strategy can improve business performance achievement. Hence, SMEs businessmen always think about how to provide the best services (Tang et al., 2007; Kohtamaki et al., 2015; and Valtakoski .and Witell, 2018.).

The service strategy based on the Tri Kaya Parisudha values for service sector SMEs has actually been implemented for a long time. From the results of preliminary interviews conducted with 4 businessmen engaged in service sector SMEs, information was obtained that the service sector SMEs always start from the thought of wanting to provide the best service to their customers. Further, this thought is implemented when providing service by speaking politely, gently, and honestly. Furthermore, it is supported by behavior to always help troubled consumers and provides solutions to their problems related to products offered. The services that have been done indeed cannot be separated from the values held by the SME businessman which are adopted from the values of local wisdom, the values or meanings contained in Tri Kaya Parisudha (Parmajaya, 2018). The Tri Kaya Parisudha values are also a guide for Balinese people in running their business, including in managing it. Therefore, this study aims to find out the service strategy model based on the Tri Kaya Parisudha values.

\section{RESEARCH METHODOLOGY}

This research used a case study approach, which is an empirical investigation that investigates contemporary phenomena contained in real-life contexts, that carried out when the boundaries between phenomena and contexts are unclear by using various data sources (Yin, 2009).The case study research used in this study is exploratory.

The key informants in this study were determined by the involvement of the person concerned with social situations/conditions that will be examined in the focus of the study. To obtain informants in this study can be done in two ways: 1) snowball samplingcan be used if the researcher is 'blind' regarding the information about the object of research, and 2) key personif the researcher already understands the initial information about both the research object and the informant.

Informants in qualitative research are those who provide information on the matter being studied (Fatchan, 2011). According to Daymon and Holloway (2002), for a case study, the sample is purposive in nature. It means 
the sample chosen is adjusted to the research objectives and needs. The focus of this study is a process of developing a service strategy model based on the Tri Kaya Parisudha values.In this study, the research informant is the 'key person', the knowledgeable stakeholders regarding the implementation of service strategies in service sector SMEs in Bali and the meaning of values contained in the Tri Kaya Parisudha.The key person consists of business stakeholders in service sector SMEs, Balinese culture experts, Hinduism experts, and academics.

Table 1

Research's Key Informant

\begin{tabular}{|l|l|c|}
\hline No & Internal & Quantity (person) \\
\hline 1 & Businessman in service sector SME & 4 \\
\hline 2 & Cultural Expert & 2 \\
\hline 3 & Hinduism Expert & 2 \\
\hline 4 & Academic & 2 \\
\hline & Total & 10 \\
\hline
\end{tabular}

Source: processed data, 2019

Based on the data in Table 1, it can be explained that the number of stakeholders used as informants consisted of four SMEs businessmen in the service sector, two Hinduism experts, two Balinese culture experts, and two academics in the Hinduism field.

Data collection techniques in this study were done through participatory observation, unstructured observation, and in-depth interviews. In participatory observation, the researcher is directly involved with the situation or environment where the symptoms occur so that the individuals are unaware of being observed, therefore the situation and activities will proceed naturally, while unstructured observation is an observation without systematic preparation regarding the matter that will be observed. Also, an in-depth interview and unstructured interview were conducted. In an unstructured interview, researchers do not use interview guidelines that are not systematically structured in gathering data but use themes to be interviewed, while an in-depth interview is carried out dialogically to obtain more in-depth information. Documentation study was also carried out in the study primarily to explore the process of implementing a service strategy based on Tri Kaya Parisudha values.

The main instrument in qualitative research is the researcher himself or the members of the research team (Sugiyono, 2017). Researchers as an instrument have their advantages compared to instruments that have been made. A priori and pre-prepared conventional instruments by researchers or orders will not be able to adapt flexibly to diverse realities. Only humans will be able to adjust and interact completely with the phenomenon being studied. In this study, researchers are only three persons accompanied by a researcher assistant.Researchers who act as an instrument, equipped with a research protocol contained with procedures and themes of research questions arranged by reflecting the flow of thoughts used as a guide or research instrument. Researchers as a research instrument are guided by the focus of research in the form of problem formulation and objectives of this study.

Based on the protocol, informants are asked to reconstruct, not to remember (Seidman, 1998). Short descriptive questions had been asked to lure informants to tell in detail the informant's experience in implementing the service strategy based on Tri Kaya Parisudha values or their understanding of Tri Kaya Parisudha valuesbased service strategy. Researchers would act as listeners to informant's story.In order for the results of the interview to be recorded properly, and the researchers possess the evidence of having interviewed the informant as a source of information, the researchers need the help of tools in the form of: 1) a notebook with function to take notes of all conversations with data sources, 2) a tape recorderwith function to record all conversations or discussions, and 3) a camera with function to document the interview.

Analysis of the data in this study follows the data analysis from Miles and Huberman (1994) which stated that data analysis is carried out interactively through the process of data collection,data reduction, data display, and data verification. Data reductionis summarizing, having the main things, focusing on important things, looking for themes, patterns and removing the unnecessary ones. Data display is the presentation of data in the form of brief descriptions, charts, the relationship between categories and the like, but the most often used to present qualitative research data is technical narrative. Next, data verification is a conclusion drawing which expected to answer the main research problems formulated from the beginning, but may also not be, because the problems and problem formulations in qualitative research are still temporary and will develop after the research.

\section{RESEARCH RESULTS AND DISCUSSION}

The discussion in this study is to articulate the meaning of data that has been done beforehand. This discussion includes the development of a service model based on Tri Kaya Parisudha's values. The results of this qualitative study provide an in-depth overview of the service strategy model applied to the service sector SMEs in Bali and the service strategy model based on the Tri Kaya Parisudha values. Previously, no prior research had been found on the Service Strategy Model based on the Tri Kaya Parisudha values. In the research methodology section, it has been stated that this research explores service strategies by integrating it with the values of Tri Kaya Parisudha, 
which consists of the dimensions of manacika, wacika, and kayika (Suhardana, 2007). All informants, in addition to conveying their perceptions on the service strategy applied to SMEs in Bali, also developed the service strategies with the values of Tri Kaya Parisudha.

\section{Service Strategy Model of service Sector SMEs in Bali Province}

The results of reduction from informants' statement are as follows: service strategies that have been implemented by SMEs, especially SMEs in the service sector in Bali are: provide the best service with quick response to customers, pay attention to customers, provide the best facilities, show capability in providing services. All service strategies implemented by service sector SMEs can be noticed by customers. In this case, the customer or consumer is the one who assesses the service strategy provided by the businessman. Virtually, the service strategy provided by the businessmen establishes from their mindset. The kind of service provided to customers naturally comes from the minds of businessmen in an abstract idea. The one who knows best is the businessmen themselves as the business strategy designers, including the formulated and implemented service strategies. Therefore, the development of this service strategy model is seen from the perspective of a producer, which initiates from his thoughts, words, and actions in carrying out services.

\section{Tri Kaya Parisudha-Based Service Strategy}

The results of the reduction of informants' statements are as follows:from the results of interviews with informants, it can be explained bout the relationship of Tri Kaya Parisudha values with service strategies.

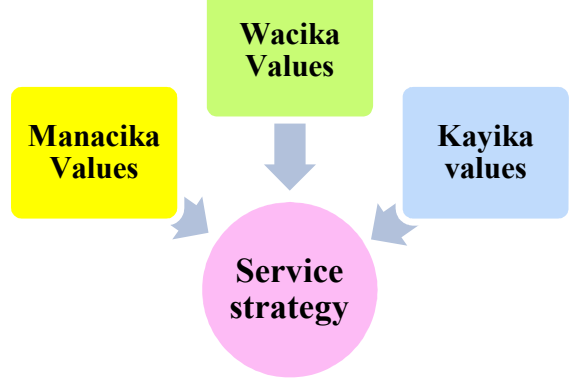

Figure 1:

Relationship of Tri Kaya Parisudha Values with Service Strategy

According to the informants' explanation, it can be said that the service sector SMEs in Bali have implemented a service strategy, and if it is associated with the values of local wisdom in Bali, which one of them is the values contained in the Tri Kaya Parisudha, it actually has already been done.Therefore, it can be explained that seen from the perspective of producers or businessmen, the service strategies of SMEs in Bali can be integrated with Tri Kaya Parisudha values, consisting of manacika, wacika, and kayika dimensions so that the service strategy concept based on Tri Kaya Parisudha values becomes a service strategy based on manacika values, wacika values, and kayika values which can be described as the following figure. Based on the explanation above, the following propositions can be formulated as follows:

Tri Kaya Parisudha-based service strategy consists of: 1) manacika values-based service strategy; 2) wacika values-based service strategy; and kayika values-based service strategy. Pictographically, the proposition is presented in Figure 2.

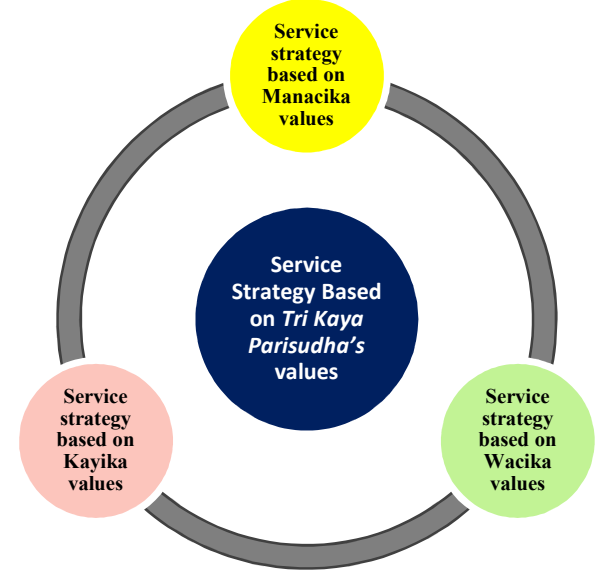

Figure 2:

Dimensions of Service Strategy Based on Tri Kaya Parisudha's values 
Furthermore, the dimensions of the service strategy based on the Tri Kaya Parisudha values are elaborated into indicators of each dimension.

\section{Description of each dimension of the Tri Kaya Parisudha}

From interviews with informants, it can be explained about the attitude and behavior of businessmen if they apply Manacika values, Wacika values, and Kayika values. Based on the informants' explanation, the following minor propositions can be formulated:

Manacika values-based service strategy.

Manacika's values can be demonstrated by: 1) think of providing the best service at all times; 2) think

of providing benefits at all times; 3) think of maintaining a good relationship with people at all times.

Pictographically, the proposition is presented in Figure 3

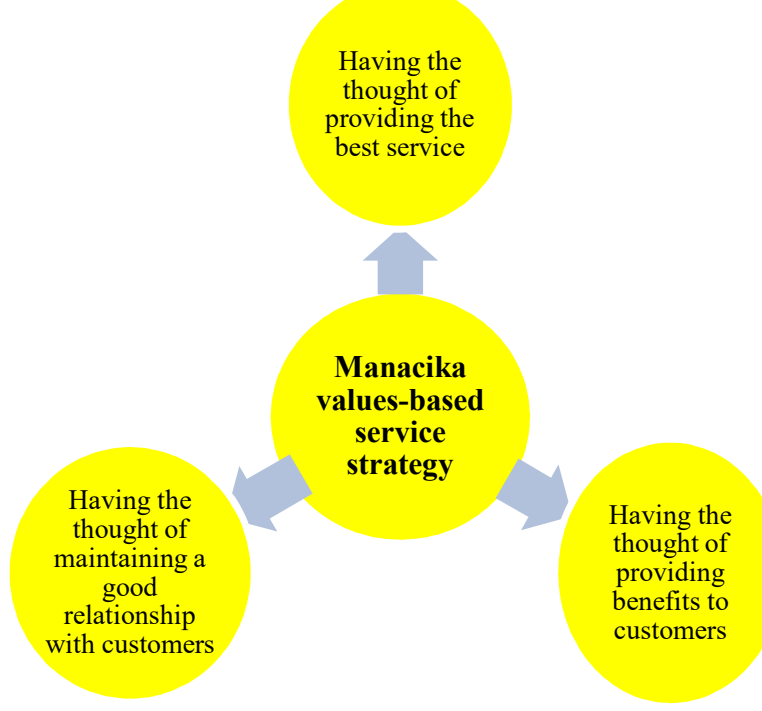

Figure 3:

Indicators of Manacika Values-Based Service Strategy Variable

\section{Wacika values-based service strategy}

Wacika's values can be demonstrated by: 1) speak politely under any circumstances; 2) speak gently under any circumstances; 3) speak honestly under any circumstances

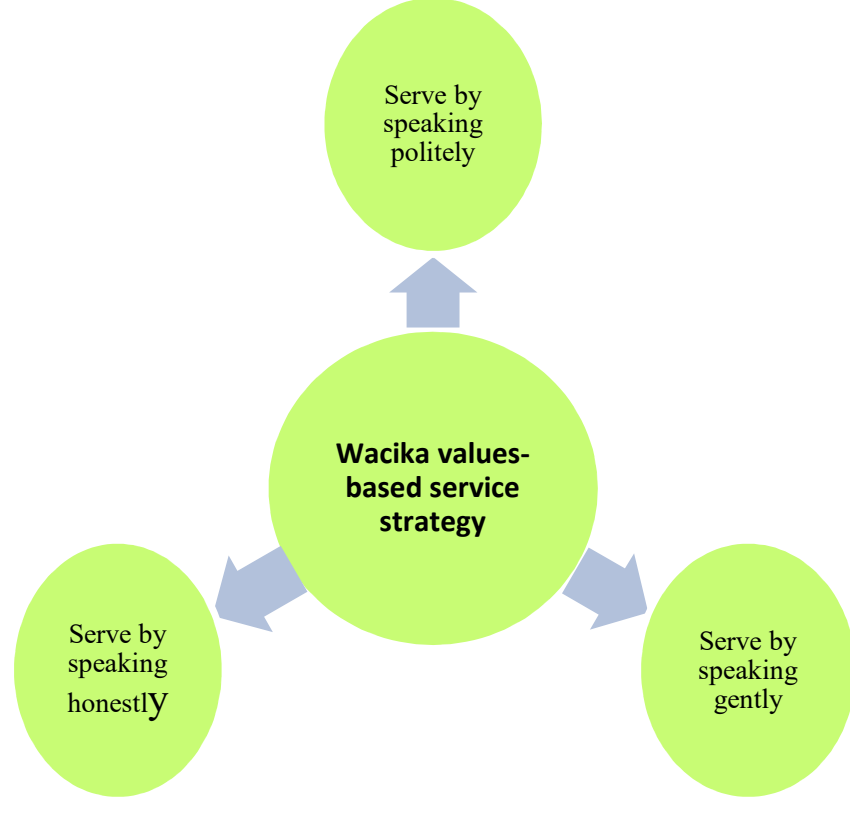

Figure 4:

Indicators of Wacika Values-Based Service Strategy Variable 


\section{Kayika values-based service strategy}

Kayika's values can be demonstrated by: 1) always helping people; 2) always pay attention to others

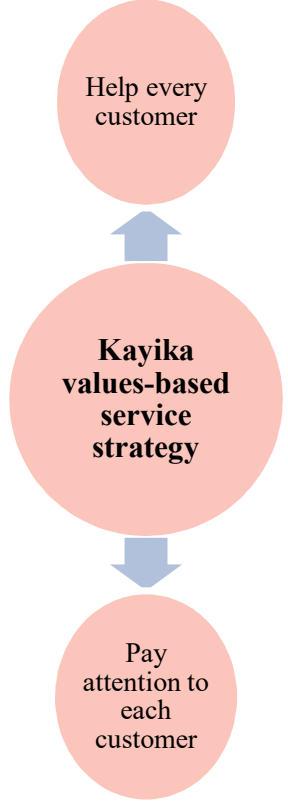

Figure 5:

\section{Indicators of Kayika Values-Based Service Strategy Variable}

\section{RESEARCH IMPLICATION}

As has been stated in the analysis and discussion that this research could theoretically find that service strategies can be integrated with the values contained in the Tri Kaya Parisudha concept viewed from the perspective of producers or businessmen. The service strategy carried out by SMEs in Bali always puts forward the meaning of manacika values, which always begin from thinking of providing the best service, followed by providing services with speaking good words and carrying out the service strategy by doing good. This is a development of the previous service strategy concept, which places more emphasis on the procedures for serving through good communication, and good implementation, as well as providing good facilities.

The concept of service strategy based on Tri Kaya Parisudha's valuescompletes it by including the meaning of the values contained in Tri Kaya Parisdha, which starts from being a right-minded on the producer side.It contributes ideas to the service sector SME stakeholders to consistently maintain and develop service strategies that adopt the Tri Kaya Parisudha values. In terms of the benefits of theory, the results of this study develop service strategy theory according to Parasuraman which consists of Tangible, Reliability, Assurance, Responsive, and Empathy into service strategies based on manacika values, wacika values, and kayika values.

\section{RESEARCH LIMITATION}

Various limitations were also found in this study mainly due to the following matters. 1) The results of the study are still limited to propositions that must be continued to become hypotheses; 2) The values of local wisdom in Bali are not only Tri Kaya Parisudha, but there are many other values of local wisdom that can be developed, such as Catur Paramitha, Tatwam Asi, Karmapala and other values; 3) This research only looks at service strategies from the perspective of producer/businessman and has not seen from the consumer's side.

\section{CONCLUSION}

Based on the results of this study, discussion, and interpretation that have been described previously by referring to several theories and the results of previous studies, it can be concluded that a service strategy model based on the Tri Kaya Parisudhais a service strategy seen from the perspective of producer, consisting of manacikavaluesbased service strategy, wacikavalues-based service strategy, and kayika values-based service strategy. Each dimension of the Tri Kaya Parisudha-based service strategyhas indicators, which has the total of eight indicators: having the thought to provide the best service, having the thought to provide benefits, having the thought to maintain good relationship, speaking politely, speaking gently, speaking honestly in providing service to consumers, being responsive to help consumers, and paying exceptional attention to consumers.

\section{REFERENCES}

Ambroise, L., Prim-Allaz, I., Teyssier, C. and Peillon, S. (2018), "The environment-strategy-structure fit and 
performance of industrial servitized SMEs", Journal of Service Management, Vol. 29 No. 2, pp. 301-328.

Benyoussef Zghidi, A. and Zaiem, I. (2017), "Service orientation as a strategic marketing tool: the moderating effect of business sector", Competitiveness Review, Vol. 27 No. 1, pp. 40-61.

Daymon, C. and Holloway, I. (2002). Qualitative Research Methods in Public Relations and Marketing Communications. London: Routledge

Fatchan (2011). Metode Penelitian Kualitatif, Cetakan Kedua, Jenggala Pustaka Utama, Surabaya.

Kohtamaki, M., Hakala, H., Partanen, J., Parida, V. and Wincent, J. (2015), "The performance impact of industrial services and service orientation on manufacturing companies", Journal of Service Theory and Practice, Vol. 25 No. 4, pp. 463-485.

Kwak, K. and Kim, W. (2016), "Effect of service integration strategy on industrial firm performance", Journal of Service Management, Vol. 27 No. 3, pp. 391-430.

Miles and Huberman (1994). Qualitative Data Analysis, 2 nd edition. Thousand Oaks, CA: Sage Publications

Parmajaya I Putu Gede, (2018), Ajaran Tri Kaya Parisudha Sebagai Landasan Pendidikan Nilai Moral dan Etika Dalam Membentuk Karakter Anak, Purwadita, Vol. 1, No. 1, pp. 33 - 40

Seidman, I. (1998). Interviewing as Qualitative Research A Guide for Researchers in Educationand the Social Sciences. New York : Teachers College Press

Sugiyono. (2017). Metode Penelitian Bisnis. Bandung: CV. Alfabeta

Suhardana K. M., (2007), Tri Kaya Parisudha: Bahan Kajian Untuk Berpikir Baik, Barkata Baik, Berbuat Baik, Surabaya, Penerbit : Paramita.

Tang, Y., Wang, P. and Zhang, Y. (2007), "Marketing and business performance of construction SMEs in China", Journal of Business \& Industrial Marketing, Vol. 22, No. 2, pp. 118-125.

Valtakoski, A. and Witell, L. (2018), "Service capabilities and servitized SME performance: contingency on firm age", International Journal of Operations \& Production Management, Vol. 38, No. 4, pp. 1144-1164.

Yin, R.K. (2009). Case Study Research: Design and Methods. Forth Edition, London: Sage Publication. 